\title{
EL FENÓMENO DE LOS OBJETOS COTIDIANOS EN EL PERIODO DE POSGUERRA Y EL DISEÑO DE INTERIORES MEDIANTE LA ELECCIÓN CREATIVA: BANHAM, LOS SMITHSON Y EL ARTE DE HABITAR
}

\author{
Sung-Taeg Nam*
}

Tras la Segunda Guerra Mundial, Banham reflexionó sobre una situación inédita entre los arquitectos, ya que con la llegada de la producción industrializada dejaron de ser "diseñadores totales". En este contexto son especialmente elocuentes la "elección creativa" de objetos ready-made propuesta por Le Corbusier en 1920 y su intento de "controlar el ambiente arquitectónico frente a la elección de otros". Banham también se interesó por el "arte de habitar" de los Smithson, que en sus dos exposiciones de 1950 lograron renovar los espacios existentes disponiendo en su interior imágenes y objetos inesperados, como si los ocupantes hubieran personalizado su hábitat. Los Smithson encontraron la foto de la casa Eames con la puesta en escena de una vida corriente y reinterpretaron la estrategia de los Eames en su propia técnica de "escoger y disponer". La disposición espontánea de los objetos, comparable a actos cotidianos como los arreglos florales, puede resultar esencial y meritoria. Gracias a la distinción entre los objetos-contenido y la arquitecturacontinente, el arte de habitar influye en el arte de la arquitectura, al igual que los elementos de catálogo utilizados en el Baukunst 0 arte de construir. En cualquier caso, es fundamental que la elección no pierda su audacia y deje atrás los convencionalismos.

Palabras clave: Banham, elección creativa, Smithson, Arte de habitar, Casa Eames

Keywords: Banham, Design by choice, Smithson, Art of Inhabitation, Eames House

\begin{abstract}
"De todas formas, en muchas ocasiones sucederá que el esmerado diseño de un arquitecto quedará asfixiado bajo un equipamiento elegido no por un colega ni por un diseñador de interiores con sensibilidad, sino por un morador normal y corriente. Es un ejemplo clásico de conflicto entre el gusto de las masas y las preferencias de una élite"
\end{abstract}

\section{BANHAM Y EL "DESIGN BY CHOICE"}

En "Design by Choice" (Diseñar por elección), publicado en 1961 por The Architectural Review, Reyner Banham describe la situación de los arquitectos en ese momento respecto al entorno visual conformado por los objetos domésticos.

Banham comprueba que en los años posteriores a la Segunda Guerra Mundial los arquitectos, enfrentados al omnipresente diseño industrial heredado de la tradición del arte aplicado y a la consolidación de los productos industrializados, pierden poco a poco su estatus de "'diseñadores totales' o 'responsables del ambiente en su conjunto"'2. Únicamente se exceptúan aquellos casos en que se encarga al arquitecto que diseñe también el revestimiento de esos nuevos objetos incontrolables, como pueden ser los electrodomésticos (Fig. 1) (lo que Banham define como "'equipamiento integrado' en el que todo lo que el arquitecto es incapaz de proyectar se amontona dentro de armarios que sí puede definir" ${ }^{\prime}$ ), o aquellos otros casos de arquitectos modernos de comienzos del siglo xx que, por ejemplo, rechazaban la desagradable presencia de los radiadores de fundición y diseñaban cubrerradiadores para esconderlos ${ }^{4}$.

En la posguerra se hace evidente que el ejercicio del arte total (Gesamtkunst) ya no se adapta a la nueva situación, pierde poco a poco vigencia y obliga a los arquitectos a plantearse la necesidad de cambiar de actitud. Según Banham, "esto, nuevamente, no conlleva exigirle al arquitecto que decline toda responsabilidad sobre el equipamiento de los edificios que debe diseñar, ya que es posible abandonar la posición de dominio autocrático implícita en la teoría de la Bauhaus sin perder el control sobre el diseño global"5.

Por lo tanto, Banham sostiene que, contrariamente a lo que ocurre con el "ambiente arquitectónico" cuyo interior es absolutamente neutro y sin ningún posicionamiento en relación con los objetos, el arquitecto no debe desentenderse de su responsabilidad respecto al ambiente construido, o al menos respecto al espacio interior que ha proyectado, aunque se muestra igualmente seguro de que tampoco se debe retomar el camino iniciado por la Bauhaus.

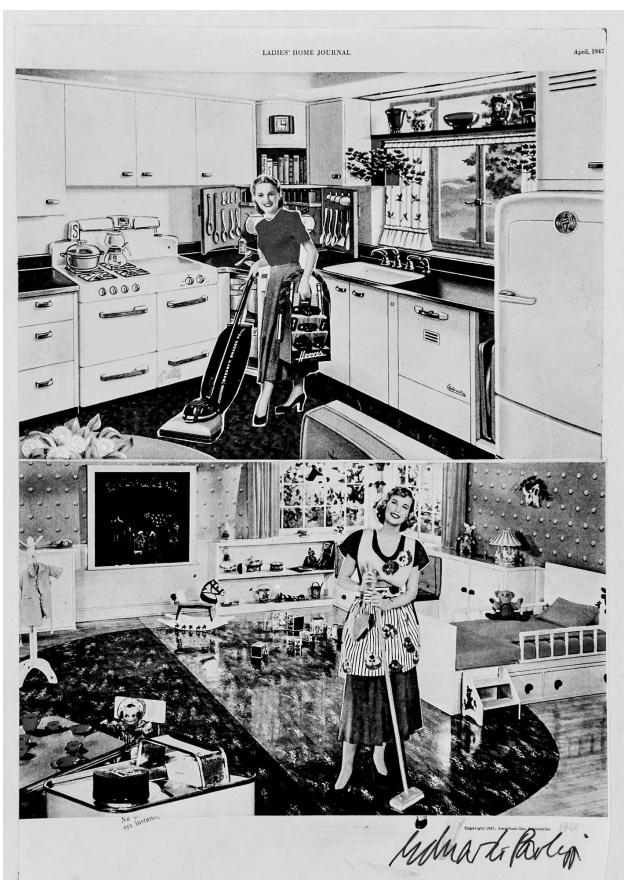

Fig. 1. E. Paolozzi, It's a Psychological Fact Pleasure Helps your Disposition (1948), collage.

* Este trabajo ha sido posible gracias al apoyo a la investigación de la Universidad Hanyang (HY-2017).

1. BANHAM, Reyner, "Design by Choice", en The Architectural Review, julio de 1961 y reimpreso en BANHAM, Mary (ed.), A Critic Writes: essays by Reyner Banham, University of California Press, Berkeley, 1996, p. 73.

2. Ibid., pp. 70-71 
Fig. 2. Le Corbusier, pabellón de L'Esprit Nouveau (1925), publicado en el capítulo "Un seul corps de métier", en Le Corbusier, Almanach d'architecture moderne (1925).
3. Ibid., p. 73. Banham prosigue con la explicación de la estrategia moderna del "equipamiento integrado": "Puede que esta propuesta no sea nada nuevo, pero merece la pena insistir porque todavía es necesario tomar medidas a este respecto. [...] De todas formas, en muchas ocasiones sucederá que el esmerado diseño de un arquitecto quedará asfixiado bajo un equipamiento elegido no por un colega ni por un diseñador de interiores con sensibilidad, sino por un morado normal y corriente. Es un ejemplo clásico de conflicto entre el gusto de las masas y las preferencias de una élite. [...] La solución de Le Corbusier de incorporar a la construcción tanto mobiliario integrado [...] Para que el arquitecto senciIlamente 'aleje de sí el dolor' [... y y la idea de diseñar un 'ambiente arquitectónico' de estudiada neutralidad [...] no hay manera de colocar una puerta y una ventana en un espacio rectangular sin establecer una relación que puede echarse perder por culpa de un televisor mal ubicado. [...] arquitectura pesimista con indicaciones preestablecidas sobre dónde colocar las cosas". Ibid. pp. 73-75. Véase también SMITH SON, Peter y Alison, Changing the Art of Inhabitation: Mies' Pieces, Eames' Dreams, the Smithsons, Artemis, Londres Zúrich, 1994, p. 110, traducido al español por Sofía Estévez como Cambiando el arte de habitar: piezas de Mies, sueños de los Eames, Ios Smithson, Gustavo Gili, Barcelona, 2001 pp. 110: "Tanto para el purismo como para la Bauhaus e mobiliario es 'equipamiento'. Sin embargo, para nosotros, y retrocediendo tres décadas (de finales de los cincuenta a finales de los veinte), resulta obvio que no es un 'equipamiento anónimo', sino mobiliario como en cualquier otro período. Se incluía en la misma estética y portaba la misma idea que la arquitectura. Ejemplos [...] los armarios para una habitación [...] en la Exposición de Bruselas de 1935 que se habían diseñado especialmente para parecer equipamiento de oficina, o el banco para almacenar de la cas de la exposición del Salon d'Automne de 1929, que parecen accesorios una tienda de lencería cara. Para los arquitectos de los años veinte apenas existía un 'equipamiento anónimo' real. Por una parte, las cosas que elegían, como el fregadero y los azulejos blancos, eran objetos de oficios que retenían algo de la fase inconsciente de la revolución industrial y, por otra parte, los electrodomésticos que seleccionaban [...] s debían tanto a la ingenuidad de la industria como a cualquie deseo de líneas puras".

4. Para profundizar en este tema, véase NAM, Sung-Taeg, "Le radiateur chez Le Corbusier", en Massilia: Annuaire d'études corbuséennes, 2012.

5. BANHAM, Reyner, "Design by Choice", op. cit., p. 73

6. Ibid. Véase la frase siguiente: "(nota: Este modus operand tenía una sola excepción: la unidad de aparador exento que de hecho, Le Corbusier había diseñado como prototipo de fabricación para Thonet)".

7. Ibid.

8. De este modo, el pabellón de Le Corbusier se aleja sutilmente del "ambiente arquitectónico"; es decir: de ese interior absolutamente neutro sin ningún posicionamiento en relación con los objetos. La exposición de Le Corbusier es similar a la de los objetos encontrados de los dadaístas 0 surrealistas.

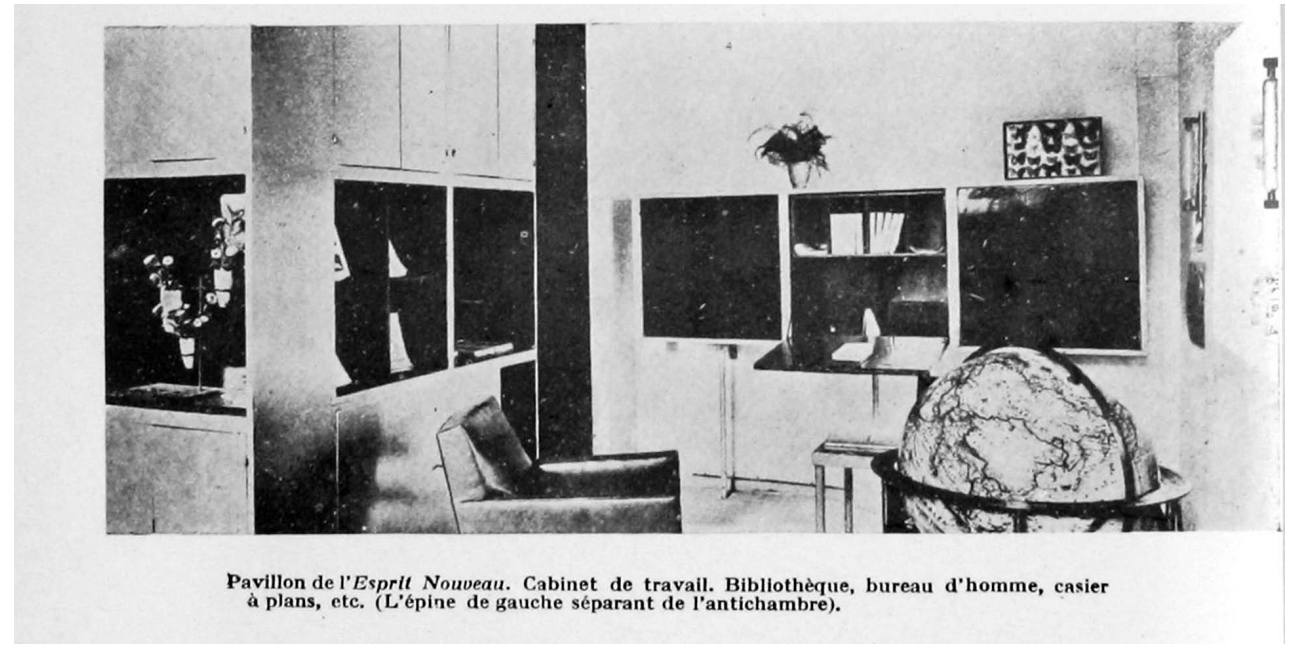

\section{LA "ELECCIÓN CREATIVA" DE LE CORBUSIER SEGÚN BANHAM}

En cambio, Banham descubre en Le Corbusier a un arquitecto visionario, que aporta una solución interesante que el historiador denomina "elección creativa" (creative choice). Seducido por el pabellón de L'Esprit Nouveau (Fig. 2), en el que Le Corbusier expone un espacio doméstico integrado por productos de catálogo, Banham escribe: "Una mínima capacidad de adaptación permite a un arquitecto hacer lo que Le Corbusier anticipó ya en 1925: 1levar a cabo una elección creativa. Su pabellón de L'Esprit Nouveau estaba completamente amueblado y equipado con artículos de catálogo de distintos fabricantes, sin que el arquitecto tuviera que diseñar nada".

Banham puntualiza que las elecciones de Le Corbusier no son únicamente funcionales, sino que además son "audaces" y van más allá de todo convencionalismo y del "gusto de las masas": "Su elección está condicionada por una idea clara de la función del edificio, y si no encuentra nada en los catálogos disponibles tiene que hacerse con otros catálogos y elegir con audacia: ningún mueble del pabellón de L'Esprit Nouveau provenía de catálogos de fabricantes de mobiliario 'doméstico', sino que se trataba de equipamiento para fábricas y oficinas. Desde luego, este es uno de los puntos en que la profesión de la arquitectura debe colaborar con el diseño industrial. Aunque sin duda alguna la convincente unidad del efecto global se vio favorecida por el hecho de que las habitaciones se habían diseñado de acuerdo con el estilo de los objetos que iban a amueblarlas (y esta es una lección que conviene tener en cuenta), toda la actuación supuso un triunfo de esa elección audaz y rigurosa de entre lo que estaba a mano"7.

El pabellón de L'Esprit Nouveau simula un interior habitado y amueblado por un ocupante cuyas elecciones, desde el punto de vista de la decoración, el amueblamiento y la disposición de los elementos, reflejan su personalidad: la del hombre-tipo de la sociedad moderna de principios del siglo xx. Pero de esta lectura se deduce que en este caso el hombre no es otro sino el propio Le Corbusier, ya que es él quien ha acondicionado el espacio. Al fundirse con el habitante imaginario del pabellón, el arquitecto expone sus elecciones con un objetivo didáctico ${ }^{8}$.

Banham señala brillantemente que la táctica de Le Corbusier no consiste en imponer un diseño preciso de formas, sino en "controlar el ambiente frente a elecciones ajenas". El artículo de Banham concluye: "En resumen, la renuncia del arquitecto a su derecho de ser la máxima autoridad del medio visual no ha reducido significativamente el alcance de su responsabilidad real ni respecto a lo visual ni respecto a lo funcional. De hecho, sus obligaciones han aumentado: el ámbito es menor, pero ahora toca cavar hasta el fondo. El modo de llevar a la práctica esta responsabilidad no consiste simplemente en asumir el control de las escuelas y esperar que todo el mundo acepte los estándares arquitectónicos como normas de referencia, tal como pretendían los teóricos de los años treinta; sino en escoger y controlar el ambiente frente a elecciones ajenas, en aconsejar, sugerir y exigir sobre la base del conocimiento y la comprensión. Es previsible que esto no redunde en el prestigio del arquitecto tanto como asignar el propio nombre a cada artículo diseñado, pero puede resultar 


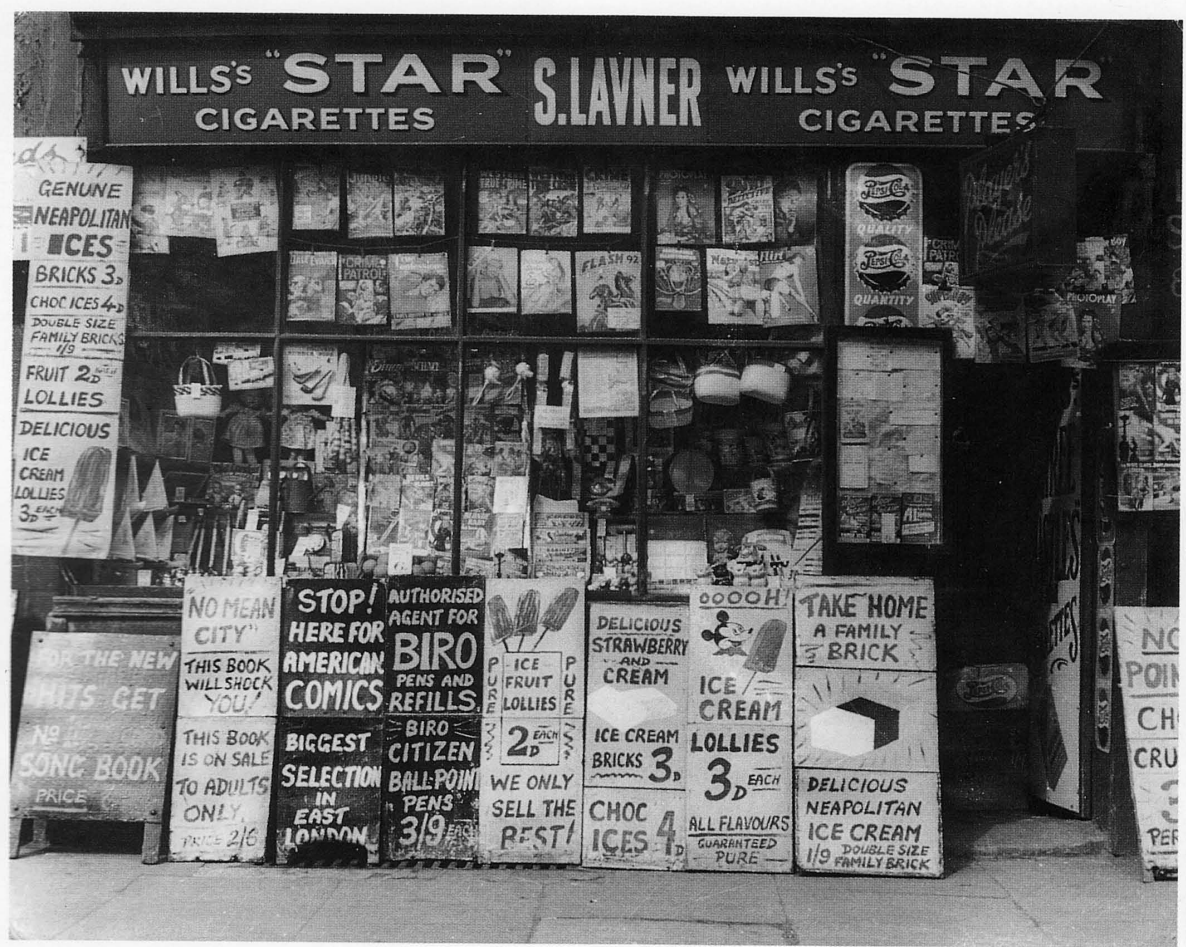

Shop front, Bethnal Green, 1949-53.
Fig. 3. N. Henderson, Bethnal Green (1949-1953), fotografía. en un trabajo más útil y en un mejor servicio a los clientes. Si ese fuera el caso, diez años de incertidumbre y discusiones no habrán sido en vano".

Puede decirse que, con la muestra del pabellón de L'Esprit Nouveau, Le Corbusier quiere asumir precisamente el papel de Wohnungslehrer ${ }^{10}$ (profesor de vivienda), de acuerdo con la expresión acuñada por Adolf Loos cuando describe la nueva misión del arquitecto respecto al acondicionamiento interior.

\section{LOS SMITHSON Y EL "AS FOUND"} "Al arquitecto le resulta posible hacer que el piso parezca la propia casa y que la casita sea el ambiente
personal más idóneo. Hemos de tender a facilitar un ambiente en el cual el hombre se sienta de nuevo
dueño de su casa. En Marruecos habíase encontrado un principio de 'hábitat' que cada uno podía adaptar
libremente para sí"1.

Alison y Peter Smithson

Recuperada por Banham para su libro de 1966 El brutalismo en arquitectura, esta cita de Peter y Alison Smithson es un buen punto de partida para analizar su preocupación por el "arte de habitar". Esta necesidad de reflexión va ganando peso en Londres, sobre todo tras la guerra. Al terminar el conflicto, la capital británica se convierte en el punto de acceso europeo de la nueva cultura popular americana que explota los productos de consumo. En ese momento Londres se abre a diferentes tendencias artísticas de vanguardia ya asentadas o que están despuntando en el continente europeo: desde el cubismo, el dadaísmo, el arte merz, el ready-made o el surrealismo hasta el art brut. Todos ellos muestran interés por el concepto de los objets trouvés u 'objetos encontrados' ${ }^{12}$, así que la ciudad se convierte en un crisol cultural y artístico de objetos existentes y cotidianos.

La guerra todavía resuena a través de toda Gran Bretaña y particularmente en la capital. Las secuelas de los dos años de represión enemiga ${ }^{13}$ son evidentes por todas partes y aún con más claridad en los barrios populares, donde a menudo la reconstrucción se hizo esperar. En este contexto y con la llegada de nuevas corrientes culturales populares y vanguardistas, la posguerra define la sensibilidad de los jóvenes arquitectos como los Smithson. La imborrable experiencia de esta vida y de esta atmósfera, plasmadas en las fotografías de Nigel Henderson $^{14}$ (Fig. 3), ejercen cierta influencia sobre el brutalismo, una tendencia a la que se
9. Ibid. pp. 77-78.

10. Según Adolf Loos ya no es el arquitecto, sino el habitante, quien debe encargarse del interior de su propio hábitat, ya que su espacio debe reflejar su propia personalidad. Los arquitectos, por su parte, deben asumir un nuevo rol: el de Wohnungslehrer o 'profesor de vivienda'. Loos escribe: "Quiero ser vuestro profesor respecto a la vivienda. Vuestra casa está llena de errores, si queréis cambiar algo en ella, preguntadme y os informaré. En esta revista se contestarán todas las preguntas concernientes a vuestro hogar"; "El hogar" en LOOS, Adolf, Ornamento y delito y otros escritos, Gustavo Gili, Barcelona, 1980 (1972), p. 157, traducido por Lourdes Cirlot y Pau Pérez. Al igual que Loos expresa esta idea en sus textos, entre ellos los que redacta para su revista Das Andere, Le Corbusier publica una serie de artículos en L'Esprit nouveau. Como Loos, Le Corbusier intenta aleccionar al público para conducirlo al mundo de los objetos funcionales. Sobre este tema, véase NAM, Sung-Taeg, "La influencia de los objetos cotidianos en el acondicionamiento interior: Loos y Le Corbusier, 'profesores de vivienda'", en Ra, Revista de Arquitectura, n. 17, 2015

11. La frase es de los Smithson, citada por BANHAM, Reyner en "Manifesto", The New Brutalism, Karl Krämer Verlag, Stuttgart-Berna, 1966, p. 47. Traducido al español por Juan Eduardo Cirlot como El brutalismo en arquitectura, Gustavo Gili, Barcelona, 1967, pp. 47-48.

12. Por ejemplo, una de las figuras más representativas del collage, Kurt Schwitters, se exilió en Inglaterra a causa de la guerra. Igualmente, una de las primeras grandes exposiciones dedicadas a Marcel Duchamp tuvo lugar en la Tate Gallery de Londres en 1966

13. Durante la guerra, los constantes ataques aéreos a Londres mediante bombarderos y misiles alemanes fueron especialmente destructivos.

14. SMITHSON, Alison y Peter, Cambiando el arte de habitar, op. cit., p. 77: "Es posible que Nigel Henderson fuese capaz de acercarnos a lo efímero de la vida". 

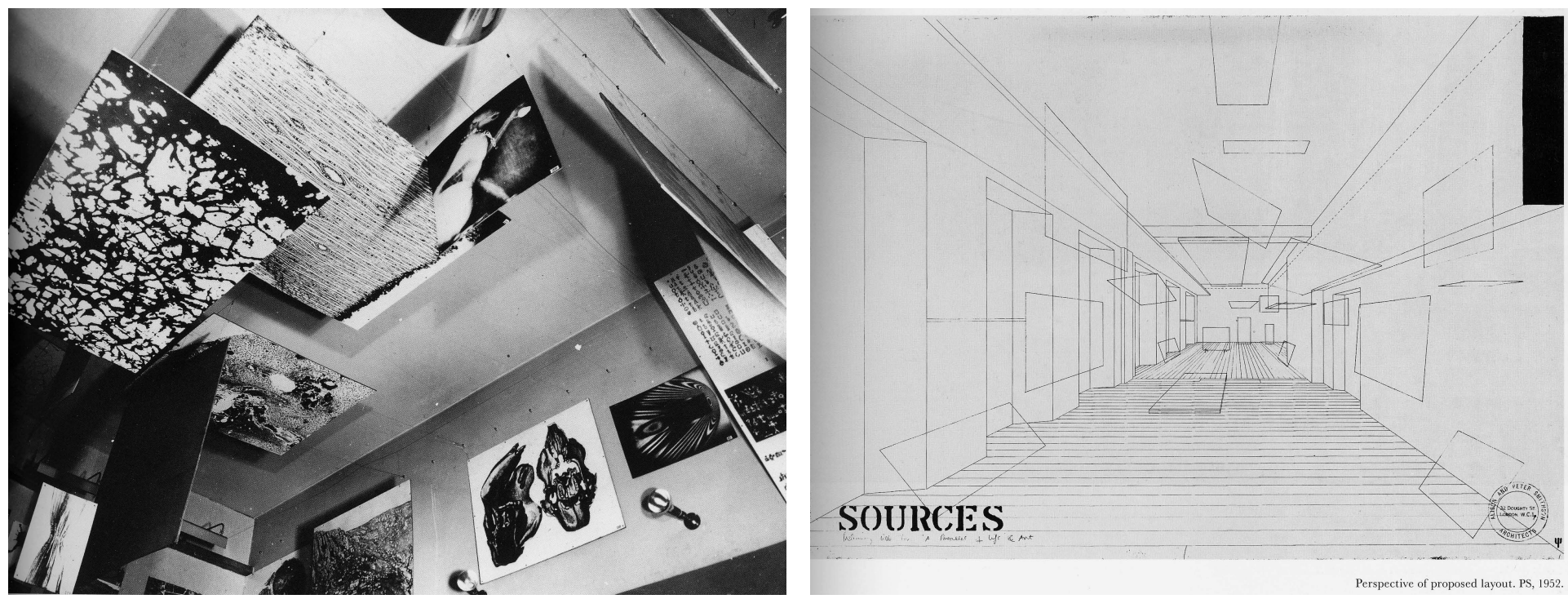

Fig. 4. P. y A. Smithson, "Parallel of Life and Art" (1953) (imagen extraída de A. Smithson, The Charged Void: Architecture. Alison and Peter Smithson (2001)).

Fig. 5. P. y A. Smithson, "Parallel of Life and Art" (1953), (imagen extraída de A. Smithson, The Charged Void: Architecture. Alison and Peter Smithson (2001)).

15. "El brutalismo intenta ser objetivo con la 'realidad', [... El brutalismo se enfrenta a una sociedad de producción masiva" (Smithson, $A D$, abril de 1957), citado por BANHAM Reyner, El brutalismo en arquitectura, op. cit., p. 47.

16. Ibid., p. 41: "no solo de las ideas convencionales de 'belleza', sino también del concepto común de lo que debe ser una 'buena fotografía"'.

17. Desde su juventud, los Smithson se interesaron por los periódicos americanos y coleccionaban las fotografías. En su artículo de 1956 "But Today We Collect Ads", afirmaron que les fascinaban las imágenes publicitarias, al igual que las imágenes de los silos y de los edificios industriales americanos habían deslumbrado a los arquitectos modernos de la primera generación

18. COLOMINA, Beatriz, "Friends of the Future. A Conversation with Peter Smithson", en October, n. 94, otoño de 2000 p. 13: "Colomina: Si observamos "Parallel of Life and Art", no se ven muchas fotografías conocidas, aunque en cierto sentido el exceso de imágenes captura la nueva realidad. / Smithson: El mensaje es bastante claro. Respondíamos con lo que considerábamos adecuado, con los recursos visuales que no habían estado al alcance de la generación anterior: fotografía fotografía aérea, microfotografía... / Colomina: Imágenes de rayos X... / Smithson: Material cuasicientífico, como el tipo que fotografiaba hombres andando. No hacíamos un énfasis especial en los anuncios. Nuestras aportaciones concretas, como la de los rayos $\mathrm{X}$ de un jeep, no eran publicitarias. / $\mathrm{Co}$ lomina: ¿De dónde las obtenían? / Smithson: Supongo que de la revista Time. El formato de Time era enorme. Sus reportajes fotográficos eran muy potentes. Paris Match también publicaba en gran formato. Era un periodo muy rico en material visual. Hoy en día esos grandes formatos han desaparecido completamente. / Colomina: Así que esas grandes imágenes de las revistas, los brillantes anuncios y el periodismo ejercieron una gran influencia en ustedes tras la guerra [...]".

19. En el marco de la exposición "This is Tomorrow", de 9 de agosto al 9 de septiembre de 1956 en la Whitechapel Art Gallery. habían afiliado los Smithson y en cuyo marco adoptan una actitud que denominan "as found" (según se encuentra) y que recuerda al concepto artístico del objeto encontrado (found object), del que se diferencia por su valor ético.

El as found incide en una mirada justa y objetiva de la realidad ${ }^{15}$, sin prejuicios, que descubra los objetos existentes mediante su exposición directa. Esta actitud de respeto ante los objetos y sus relaciones con el entorno inmediato favorece la configuración arquitectónica de un espacio con objetos reales. En última instancia, el concepto as found guarda una estrecha vinculación con el arte de habitar, como bien demuestran dos exposiciones: "Parallel of Life and Art" (Paralelismo entre la vida y el arte, 1953) y "Patio and Pavilion" (Patio y pabellón, 1956), que los arquitectos montaron en colaboración con los artistas Nigel Henderson y Edouardo Paolozzi.

Visitable en 1953 en la galería Institute of Contemporary Arts, la exposición "Parallel of Life and Art" se componía exclusivamente de reproducciones fotográficas sin relación directa con el arte ${ }^{16}$. Se trataba simplemente de imágenes encontradas, escogidas y puestas en común por cuatro vanguardistas. De hecho, muchas de ellas provenían de la colección privada ${ }^{17}$ de cada uno de ellos o de fotografías efímeras publicadas en periódicos o revistas. El resto fue fruto de elecciones espontáneas durante las reuniones para preparar la exposición ${ }^{18}$.

\section{DOS EXPOSICIONES SOBRE EL ARTE DE HABITAR}

"Parallel of Life and Art" expone imágenes poco habituales sin un hilo conductor ni un objetivo artístico. La forma de ordenarlas se aleja radicalmente de las exposiciones artísticas convencionales. Sin una ubicación ni dirección específicas y superpuestas aleatoriamente, las láminas se mezclan sin ninguna jerarquía inteligible, como si simplemente tuvieran que rellenar la habitación en que se encuentran. La acumulación de imágenes despojadas de su contexto original crea una nueva percepción, no solo de cada una de ellas, sino también de la estancia, que nada tiene que ver con lo acostumbrado. De este modo, el grupo de vanguardistas toma posesión del espacio, se adueña de él (Figs. 4 y 5 ). Se comportan de manera muy similar a los nuevos habitantes que transforman y personalizan su vivienda.

Los Smithson siguieron profundizando en este potencial de apropiación. La exposición "Patio and Pavilion"19 en la Whitechapel Art Gallery en 1956 es un ejemplo radical del arte de habitar, sobre la que sus autores explican: "En la exposición colectiva 'Patio and Pavilion', habíamos trabajado con un tipo de hábitat simbólico en el que habíamos encontrado respuestas, de una u otra forma, a las necesidades básicas del ser humano [...] un 'patio' o un sitio cerrado en el que se asienta un 'pabellón'. El patio y el pabellón se amue- 


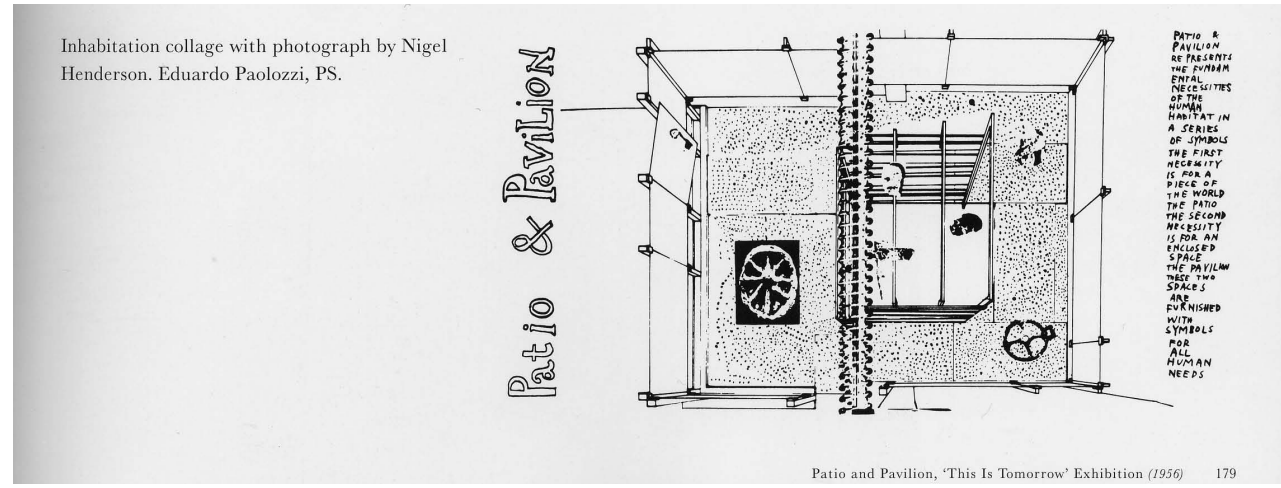

6

blan con objetos que son símbolos de las cosas que necesitamos, por ejemplo, la imagen de una rueda para el movimiento y las máquinas. El método de trabajo [...] los arquitectos proporcionan una estructura y los artistas proporcionan los objetos"20. Los Smithson se encargan únicamente de la construcción interior en la sala que les han asignado. Será después, cuando los arquitectos viajen a Dubrovnik para el CIAM X tras haber finalizado la construcción del patio y del pabellón, cuando los artistas acometan el proyecto del contenido (Fig. 6).

Peter Smithson subraya, tiempo después, el evidente reparto de roles entre los arquitectos y los artistas durante su conversación con Beatriz Colomina: "Smithson: Entonces nos fuimos a Dubrovnik y los otros dos... / Colomina: ¿Nigel y Edouardo? / Smithson: Sí. Se ocuparon del resto. Vamos, que no lo habiamos planeado asi en absoluto. El mensaje es que el arquitecto ejecuta los espacios, que el ocupante toma posesión haciéndolo suyo... I Colomina: Así que Nigel y Edouardo fueron los ocupantes. / Smithson: Sí, no lo decoramos nosotros; fueron ellos"21.

Los arquitectos eligen descargar a la construcción del peso de la originalidad con tipos tradicionales, formas anodinas y materiales pobres. La originalidad se concentra en la disposición de los objetos propuesta por los artistas y que subvierte la percepción de los visitantes. El interior ocupado por los artistas sorprende incluso a los arquitectos a su vuelta del CIAM. Los artistas renuevan totalmente el espacio y se adueñan de él, como habían hecho los Smithson en "Parallel of Life and Art". Es interesante que los arquitectos consideren esta actuación como una elección de amueblamiento: los artistas, en cuanto habitantes ${ }^{22}$, ocupan el espacio con sus objetos, aportan su decoración ${ }^{23}$, y su intervención se caracteriza por una expresión autónoma únicamente regida por el marco arquitectónico proporcionado por los arquitectos. El arte de habitar crea una nueva percepción no menos valiosa que la creada por el arte de construir.

\section{LA "ESTÉTICA EAMES" (CON OBJETOS COTIDIANOS) SEGÚN LOS SMITHSON}

“Se pueden considerar la casa de los Eames y 'Patio and Pavilion' como fenómenos paralelos"24.

Alison y Peter Smithson

Los Smithson descubrieron la casa Eames (Case Study House n. 8, construida en 1949 por la pareja de diseñadores americanos Charles y Ray Eames) gracias a las fotografías publicadas por los medios de comunicación. Esta emblemática residencia impactó en ellos inmediatamente.

De entre todas las imágenes, una de la sala de estar, que difiere profundamente de las fotografías convencionales de arquitectura, se convirtió en el tema central de varias publicaciones de los Smithson (Fig. 7). Por lo general, la difusión mediática de una construcción se lleva a cabo durante la inauguración del edificio, antes de que entre en uso y se degrade; debe presentarse la obra arquitectónica como un vehículo nuevo, recién salido de fábrica. Por el contrario, la fotografía de la casa Eames que fascina a los Smithson representa un interior

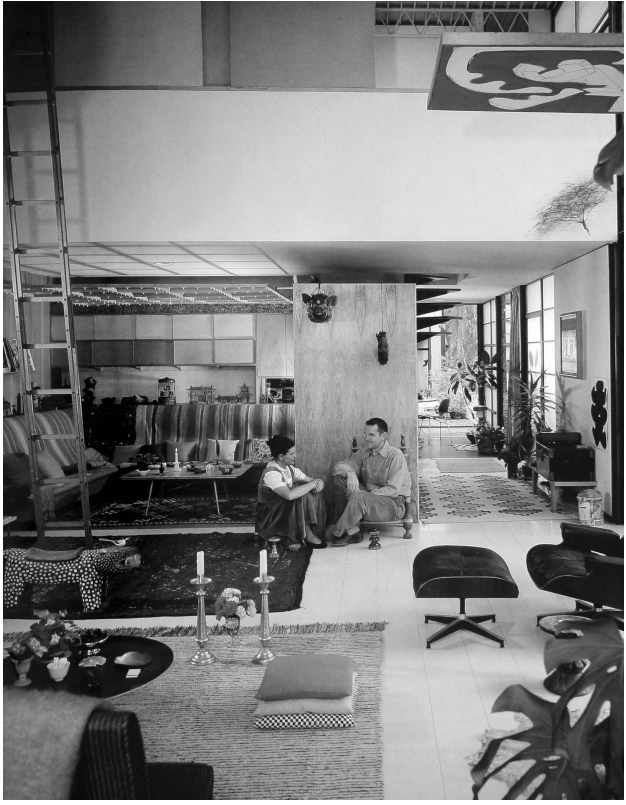

7

Fig. 6. P. y A. Smithson, "Patio and Pavilion" (1956), "Inhabitation Collage", con dibujo de fondo de P. y A. Smithson y fotografía superpuesta de N. Henderson y E. Paolozzi, (imagen extraída de A. Smithson, The Charged Void: Architecture. Alison and Peter Smithson (2001)).

Fig. 7. C. y R. Eames, casa Eames (1949), sala de estar, (imagen extraída de Donald Albrecht (ed.), The Work of Charles and Ray Eames: a Legacy of Invention (1997)).

20. SMITHSON, Alison y Peter, Cambiando el arte de habitar, op. cit., p. 109. Algunos objetos colocados por los dos artistas recuerdan al ready-made, como la Rueda de bicicleta (1913) de Marcel Duchamp.

21. COLOMINA, Beatriz, "Friends of the Future [...]", op. cit., p. 27. Véase la conversación siguiente: "Colomina: Entonces, ustedes no tuvieron nada que ver con los objetos que estaban allí, aquella rueda, aquella televisión... / Smithson: No, no nos encargamos de eso. Mi interpretación fue que se trataba de representaciones de máquinas y de animales, pero que nada era concreto, nada era real, todo era metafórico. / Colomina: ¿Llegaron para la inauguración? / Smithson: Fue extraordinario. Tuvo lugar mucho antes de las instalaciones de objetos reales que tan habituales son hoy en día. [...] / Colomina: ¿Le gustó cómo Nigel y Edouardo ocuparon su proyecto? / Smithson: Sí, estaba maravillado. Cuando te vas no hay nada; vuelves dos semanas después y parece un milagro. No se trataba de una reinterpretación de otra cosa, como Peter Blake. Se trataba de algo nuevo".

22. Por otra parte, conviene recordar que los espectadores también forman parte de la exposición. El muro está recubierto por paneles de aluminio que reflejan como un espejo hasta tal punto que los visitantes sienten que la sala interior se transforma en un patio exterior en medio de un edificio. Su reflejo en los paneles de aluminio se confunde con las siluetas de los habitantes en el interior de unas ventanas que no son tales. La puesta en escena refuerza la percepción de la obra como un hábitat realmente habitado y en continuo cambio.

23. Contrariamente a lo que ocurre con la decoración tradicional, los Smithson no consideran que el arte de habitar sea secundario, sino que se trata de un arte autónomo respecto de la estructura, la construcción y la forma de la arquitectura. 24. SMITHSON, Alison y Peter, op. cit., p. 99. 


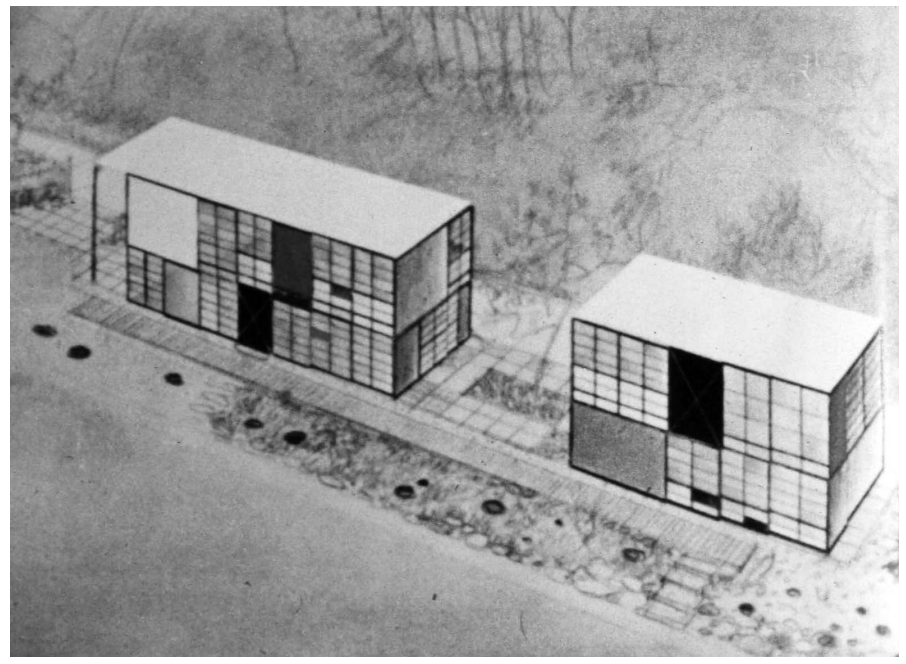

8

Fig. 8. C. y R. Eames, casa Eames (n. 8, 1949), (imagen extraída de John Neuhart (ed.), Eames Design: the Work of the Office of Charles and Ray Eames (1989)).

Fig. 9. C. y R. Eames, armario modular ESU, (imagen extraída de John Neuhart (ed.), Eames Design: the Work of the Office of Charles and Ray Eames (1989)).

25. SMITHSON, Alison y Peter, Cambiando el arte de habitar, op. cit., p. 72. Véase también Ibid., p. 87: "La manera Eames de entender el material tenía el efecto de renovar los objetos que mostraban, de modo que se veían como por primera vez, sus cualidades se proyectaban en el espacio de su escenario, fusionándose con él”.

26. Ibid., p. 72

27. Idem, p. 72: "En la década de los cuarenta, los Eames alejaron el diseño de la estética de la máquina y de la tecnología de la bicicleta, donde había residido desde los años veinte, para introducirlo en el mundo de la visión cinematográfica y la tecnología de la producción aeronáutica. Del mundo de los pintores al mundo de los diseñadores. En cierto sentido, tanto la estética-máquina como la estética-Eames son formas artísticas de la vida cotidiana y de los objetos cotidianos vistos desde la perspectiva que considera lo cotidiano también como algo mágico". Véase también Ibid., p. 81: "[...] el hágalo-usted-mismo de espléndidos catálogos, el pensa de Sears-Roebuck... el conjunto del modo de pensar y vivir en-ampliación, con-enchufe, de-acampada, venido-de-vertedero [...] como el barro cae de las ruedas de un camión".

28. Véanse los escritos de Adolf Loos: "Por aquel entonces se amueblaba igual que hoy se viste. Del zapatero se toman los zapatos, del sastre la levita, los pantalones y el chaleco del fabricante de camisas, cuellos y puños, del sombrerero el sombrero, del tornero el bastón. Ninguno conoce al otro $y$, sin embargo, coinciden en todas las cosas". L00S, Adolf, "La suppression des meubles" (1924), en Paroles dans le vide, Editions Ivrea, París, 1994, p. 284, traducido al español por Irma Huici como "Intérieurs, un preludio" en Dicho en el vacío, Colegio Oficial de Aparejadores y Arquitectos Técnicos de Murcia, Murcia, 1984, pp. 65-66.

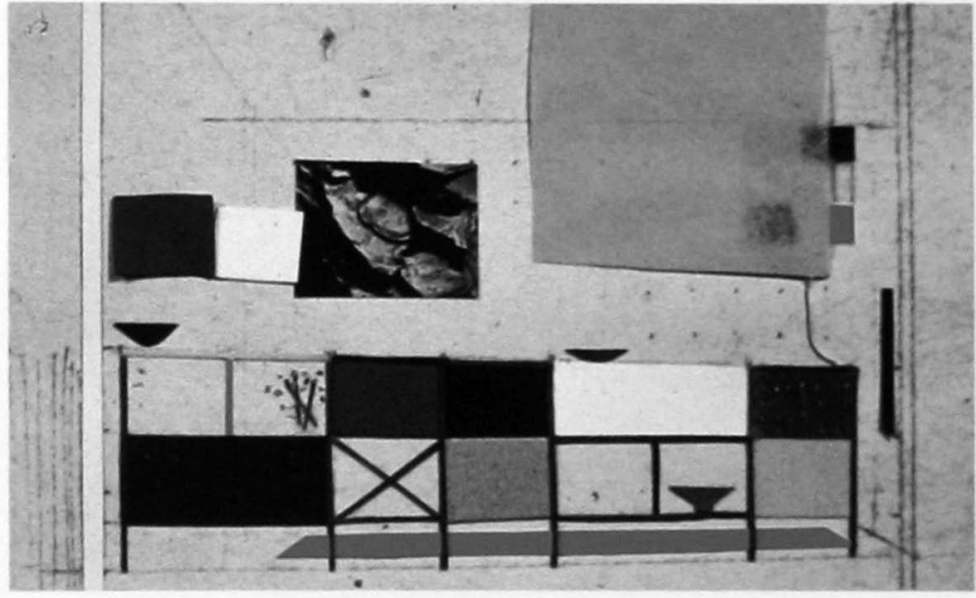

Ray's color sketch of an Eames Storage Unit

"ya habitado", más que "para ser habitado" (à habiter); nos muestra no solo la esfera privada de los habitantes (su mobiliario, sus libros...) sino también a la propia pareja Eames, que ocupa la casa, acentuando su felicidad de manera exagerada, al estilo de las películas o los anuncios de las revistas americanas de aquella época.

La casa Eames (Fig. 8) se asemeja a un plató de televisión: es un estudio, una simple caja, muy económica, construida para alojar el conjunto de objetos encontrados de sus habitantes. Puede percibirse una cierta relación con la serie de armarios modulares ESU (Fig. 9), concebidos por los Eames en los años cincuenta, y con el tipo de espacio interior presentado en el pabellón de L'Esprit Nouveau. De hecho, los Smithson ponen de manifiesto esta similitud y comparan el pabellón de Le Corbusier con el acondicionamiento interior de Eames: "En cierto sentido, tanto la estética-máquina como la estética-Eames son formas artísticas de la vida cotidiana y de los objetos cotidianos vistos desde la perspectiva que considera lo cotidiano también como algo mágico"25.

Tanto la pareja de diseñadores americanos como el arquitecto francosuizo nos descubren el verdadero valor de los objetos presentes, al alcance de la mano, aunque con una diferencia significativa en cuanto a los criterios de selección de dichos objetos. A este respecto, los Smithson subrayan: "La estética-máquina seleccionaba con cuidado aquellos objetos de la vida cotidiana que se basaban en geometrías simples [...], objetos cuya cotidianeidad se podía componer como siluetas. Es decir, los cuadros se podrían crear desde su disposición, y de ahí se podía erigir una disciplina artística. Así como se le concedió una forma canónica a la estética-máquina en la 'unidad de vivienda' del pabellón de L'Esprit Nouveau, [...] la estética de los Eames se materializó en la casa de 1949 del Cañón de Santa Mónica en California. Esta estética se basa también en una cuidada selección de criterios, pero con una sorpresa extracultural, más que armonía de siluetas"26.

La concepción maquinista del pabellón de L'Esprit Nouveau todavía respeta una línea estética pictórica: la elección de los objetos y su disposición parecen libres, y sin embargo están regidas por una teoría formal y compositiva. Aunque aparentemente los objetos del pabellón son heterogéneos, en realidad han sido seleccionados rigurosamente siguiendo los criterios sofisticados y reflexivos de la modernidad industrial, además de por su "armonía de siluetas" 27 . La certeza de Le Corbusier, al igual que la convicción de que ya no es necesario controlar formalmente los objetos de uso cotidiano, se fundamenta paradójicamente en otra convicción hipotética: que las formas estandarizadas armonizan entre ellas de manera natural, como ocurre con las prendas de vestir modernas ${ }^{28}$.

\section{DE PINTORES A DISEÑADORES}

Los objetos de la fotografía de la sala de estar de los Eames son también el producto de una selección, aunque esta no se basa en una teoría elitista y dispone de un abanico de obje- 
tos mucho más diverso que el de Le Corbusier. De hecho, resulta casi imposible distinguir un objeto en concreto, y menos aún atribuirle un valor especial como a los "objetos tipo" de Le Corbusier. En palabras de los Smithson, "Charles Eames no era arquitecto, no era hombre de planos”29. La propuesta de los Eames se desvincula así de la estética de un arquitecto para aproximarse a la de un "diseñador" del mundo del cine o de la televisión: "En la década de los cuarenta -según los Smithson- los Eames alejaron el diseño de la estética de la máquina y de la tecnología de la bicicleta, donde había residido desde los años veinte, para introducirlo en el mundo de la visión cinematográfica y la tecnología de la producción aeronáutica. Del mundo de los pintores al mundo de los diseñadores" ${ }^{\prime 30}$.

A su manera, los Eames aportan un nuevo enfoque al escenario doméstico: el encuadre se vuelve más dinámico, se manipula como si fuera una cámara. Este nuevo punto de vista se centra especialmente en una realidad inmediata a la que incorpora cierto grado de azar, y de esta espontaneidad se desprende una energía adicional. La casa Eames proporciona el marco, una especie de telón que concentra e intensifica la percepción del escenario doméstico. Aunque los objetos abarcados por el campo de visión de la cámara también pueden percibirse como los objetos de un lienzo, el encuadre es instantáneo y cambiante, muy distinto al de una naturaleza muerta cuya composición viene determinada por el objetivo pictórico del artista.

La concepción cinematográfica del marco vital despoja a la imagen de su singularidad habitual. La huella de los habitantes de la casa Eames ya no puede resumirse en una sola imagen, sino que se hace necesaria una secuencia de imágenes complejas, variadas y fragmentadas ${ }^{31}$. Solo así puede entenderse por qué el interior de esta vivienda es tan difícil de aprehender en una imagen fija y por qué recibe un trato mucho más justo cuando se reproduce mediante una serie de fotografías o un vídeo, como la película que rueda Eames en 1955 (Fig. 10).

\section{"ESCOGER Y DISPONER"}

A partir de esta estética de los Eames, los Smithson elaboran una estrategia que denominan "escoger y disponer" como la 'estética Eames': la técnica de 'escoger y disponer' que hemos utilizado al diseñar y equipar nuestras propias casas y que todavía consideramos como una técnica válida para la organización de objetos, mecanismos y servicios relativamente sencillos en edificios, donde puedan conocerse al detalle y donde se puedan introducir dentro del proceso de diseño. Esto, por supuesto, como método de diseño se acerca al arreglo floral y al buen gusto en la decoración de habitaciones con piezas de coleccionista: se utilizan los objetos para lo que son, cada objeto se ve ensalzado y habla más claramente de sí por la virtud de su disposición" ${ }^{\prime 3}$.

La estrategia de escoger y disponer es casi idéntica a la del arte de habitar que los Smithson enuncian en sus exposiciones y experimentan a lo largo de su vida profesional. Es cierto que escoger y disponer recuerda directamente a las palabras de Loos y Le Corbusier sobre el acondicionamiento interior por parte del habitante ${ }^{34}$, pero también tiene que ver con la larga tradición artística de la naturaleza muerta, el collage, el ensamblaje artístico, el montaje...

Los Smithson, sin embargo, intentan diferenciar su estrategia, y a menudo inciden en que escoger y disponer se acerca más a las prácticas de las clases populares. Entre las imágenes que ilustran su discurso no se ven referencias a las obras de las élites artísticas, sino a ejemplos de composiciones cotidianas y efímeras de labores corrientes, como el "arreglo floral" sobre una mesa, el "amueblamiento" por el habitante o las "manzanas en un plato"35 del desayuno. Sucede lo mismo con el "recoger, dar la vuelta y poner con" ${ }^{36}$, tal como se definió poco después el concepto de as found o 'según se encuentra' y que recuerda a un juego de niños. De este modo, escoger y disponer propone una norma infantil: seleccionar cualquier cosa con "ojo observador" y después disponerlo al gusto de cada cual para jugar con él. Mientras dura el juego, estos objetos encontrados se hacen propios y se transforman en objetos nobles ${ }^{40}$, incluso si se trata de objetos de mala calidad.

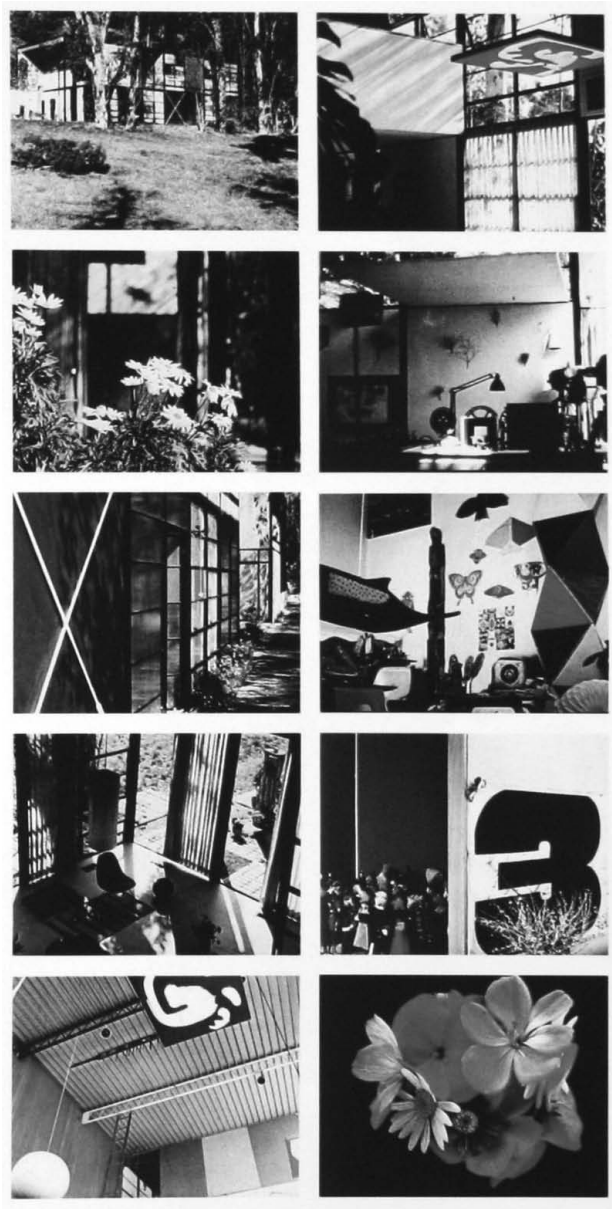

Fig. 10. C. Eames, película: House - After Five Years of Living (1955), (imagen extraída de John Neuhart (ed.), Eames Design: the Work of the Office of Charles and Ray Eames (1989)).

29. SMITHSON, Alison y Peter, op. cit., p. 101. Sin embargo, Charles también había recibido la formación y tenía experiencia como arquitecto, antes de centrarse en el diseño de muebles.

30. Ibid., p. 72.

31. Como dicen los Smithson en relación con los objetos de los Eames: "Se pueden fotografiar como fragmento", en SMITHSON, Alison y Peter, op. cit., p. 76.

32. La otra expresión, "selección y yuxtaposición". Ibid., pp. $72-74$.

33. SMITHSON, Alison y Peter, Without Rhetoric - An Architectural Aesthetic 1955-1972, Latimer New Dimensions, Londres, 1973, pp. 44-47; y también en SMITHSON, Alison y Peter, Cambiando el arte de habitar, op. cit., p. 79.

34. Loos: "Vosotros mismos podéis amueblaros vuestra casa, ya que solo así será vuestra casa. Si lo hace otra persona, sea un pintor 0 un tapicero, no será ya una vivienda. A lo sumo surgirá una suite de hotel o la caricatura de una vivienda", LO0S, Adolf, "El hogar", en Ornamento y delito y otros escritos, op. cit., p. 156. Le Corbusier: "Construir su casa es casi como hacer su testamento...", en LE CORBUSIER, "Maisons en série", en L'Esprit nouveau, n. 13, diciembre de 1921 y reimpreso en LE CORBUSIER, Vers une architecture, G. Crès, París, 1923; traducido al español por Josefina Martínez Alinari como "Casas en Serie", en Hacia una arquitectura, Apóstrofe, Barcelona, 1998 (1977), p. 195. 


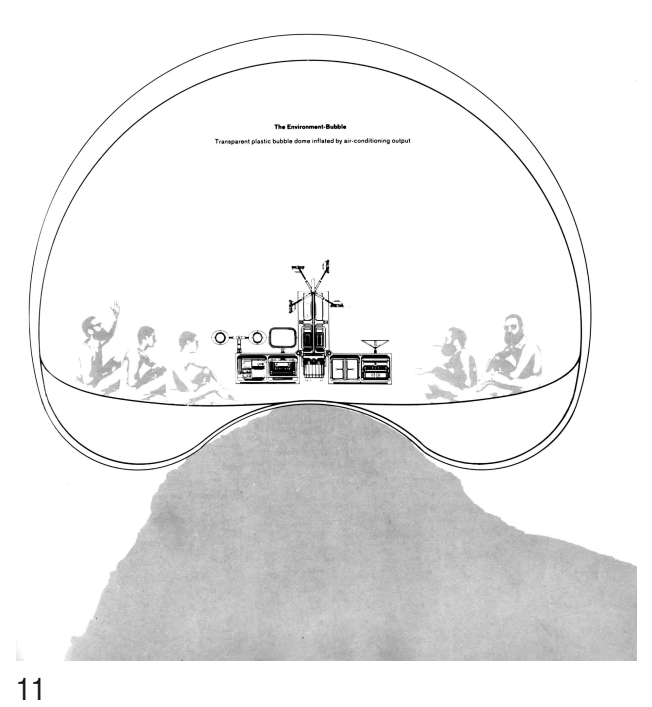

Fig. 11. Apartamento de P. y A. Smithson, (imagen extraída de VAN DEN HEUVEL, Dirk (ed.), Alison and Peter Smithson: From the House of the Future to a House of a Today (2004)). Fig. 12. R. Banham y F. Dallegret, "Un hogar no es una casa" (1965).

35. "El placer de la disposición, como 'manzanas en un plato'”, en SMITHSON, Alison y Peter, Cambiando el arte de habitar, op. cit., p. 84.

36. "Visto desde finales de los ochenta: El 'según se encuentra', donde el arte está en recoger, dar la vuelta y poner con. y 'lo encontrado', donde el arte está en el proceso y en el ojo observador...", SMITHSON, Alison y Peter, "The 'As Found' and the 'Found"', en ROBBINS, David, The Independent Group, The MIT Press, Cambridge (Massachusetts) 1990 p. 201. Traducido al español por Jorge García, Eusibi Moreno y Criso Renovell como "El 'según se encuentra' y 'lo encontrado"', en El Independent Group: la posguerra británica y la estética de la abundancia, IVAM, Valencia, 1990, p. 201.

37. Ibid.

38. SMITHSON, Alison y Peter, op. cit., p. 72.

39. Ibid., p. 104.

40. Ibid., p. 84: "al modo Eames... la disposición de los objetos corrientes de tal modo que se convierten en objetos honorables"; SMITHSON, Alison y Peter, Without Rhetoric - An Architectural Aesthetic 1955-1972, op. cit., pp. 9-10: "La transformación de objetos cotidianos en manifestaciones artísticas ocurre de múltiples formas: el objeto puede ser descubierto (objet trouvé 0 art brut) y permanecer inalterado aunque pueda surgir en torno a él una fabulación popular literaria; pero también puede utilizarse el objeto como punto de partida y someterlo a una transformación. En el volumen I de su Oeuvre complète, Le Corbusier describe cómo evolucionó el mecanismo arquitectónico de la casa Citrohan (1920): dos elementos de la cultura popular -la tipología de café (una pequeña barra de cinc al fondo con un gran ventanal a la calle) y el acristalamiento vertical con junta seca de la fábrica suburbana se combinan y transforman con una finalidad estética más propia de las bellas artes".

41. SMITHSON, Alison y Peter, Cambiando el arte de habitar op. cit., p. 74.

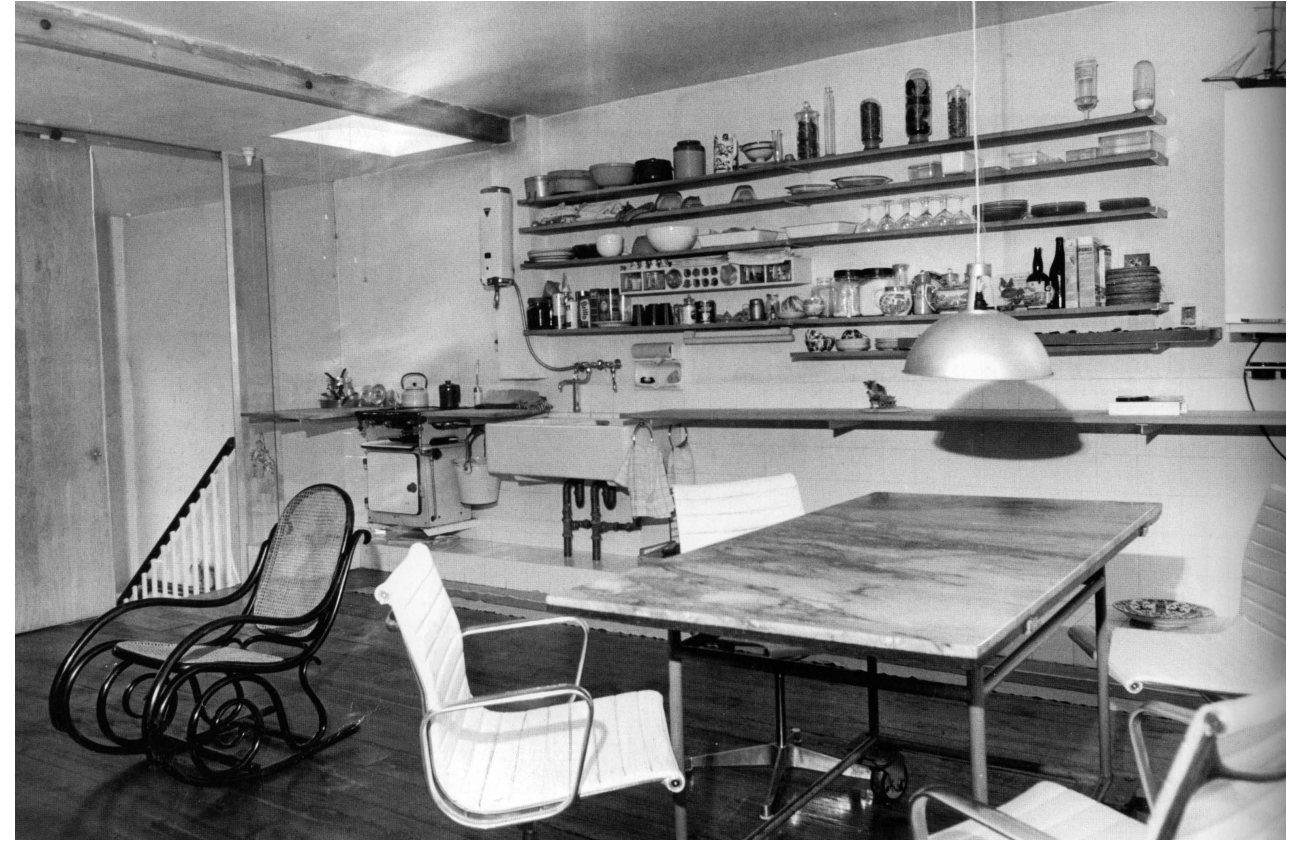

12

\section{"PERTENECEN A SUS OCUPANTES"}

Si bien, según los Smithson, el acondicionamiento interior de los Eames se traduce en una partida continua de escoger y disponer, en sus ejemplos de diseño industrial, como las famosas sillas, buscan la armonía con esos objetos cotidianos y efímeros. La estrecha relación que mantienen sus creaciones con el resto de objetos del día a día potencia la sencillez que emana de todo el conjunto y establece una cierta paridad entre todos los objetos: las sillas pueden ser desplazadas libremente o cambiadas por otras. De hecho, los Smithson comparan las sillas de los Eames con las de Mies: "Las sillas de los Eames [...] parecen como si se hubieran posado allí -el mirlo que aparece en la fotografía de las sillas de alambre no es ninguna coincidencia-. Las sillas pertenecen a sus ocupantes, no al edificio. No como las sillas de Mies, que eran sobre todo del edificio y no de sus ocupantes"41.

Banham resume el concepto de los Smithson con la expresión “adaptar la habitación del hombre a su espontáneo hábitat" 42 (Fig. 11). Una vez más, este enunciado resulta similar a la idea que ya habían expresado Loos y Le Corbusier. Sin embargo, el arte de habitar de los Smithson se diferencia por su voluntad de abandonar el papel elitista del Wohnungslehrer o 'profesor de vivienda' que asumen Loos y Le Corbusier y también por no enseñar a la población la forma correcta (ni ética ni estética) de escoger y disponer. Los Smithson opinan que el arte de habitar corresponde literalmente al hombre. Este nuevo grado de libertad alcanzado ¿significa una separación entre el contenido (objetos) y el continente (arquitectura) o una nueva reconciliación?

\section{CONTENIDO Y CONTINENTE: LA SEPARACIÓN Y EL FIN DEL ARTE DE CONSTRUIR}

El auge de los objetos ready-made en la arquitectura socava la tradición del arte total y del arte aplicado. Convencidos de la necesaria ruptura entre la producción de los objetos de uso cotidiano, en los que debe primar la utilidad, y la de los objetos artísticos, en los que debe primar la belleza, algunos arquitectos modernos como Loos y Le Corbusier defienden la introducción de los objetos ready-made en la arquitectura. La consecuencia lógica es la necesidad de un nuevo concepto arquitectónico que incida en la ruptura del vínculo entre la construcción, a cargo del arquitecto, y el acondicionamiento interior, que deben asumir sus ocupantes. Esta disociación entre los conceptos de la casa-continente y los objetos-contenido se acelera tras la Segunda Guerra Mundial. Los Smithson ya no consideran que el espacio doméstico sea una composición de objetos rigurosamente se- 


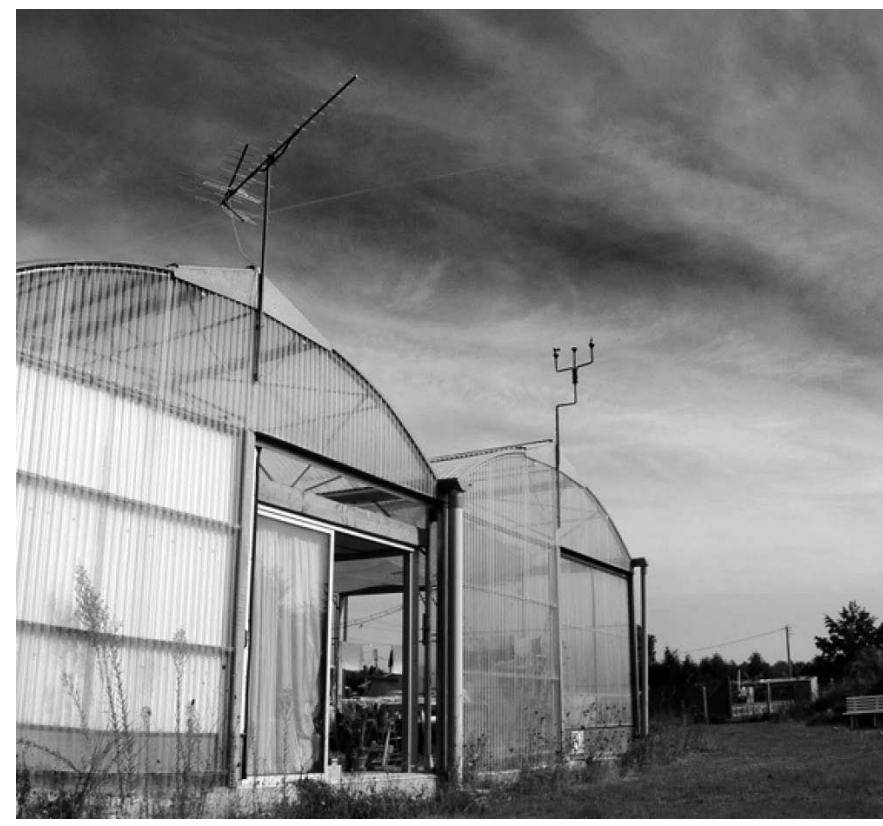

13

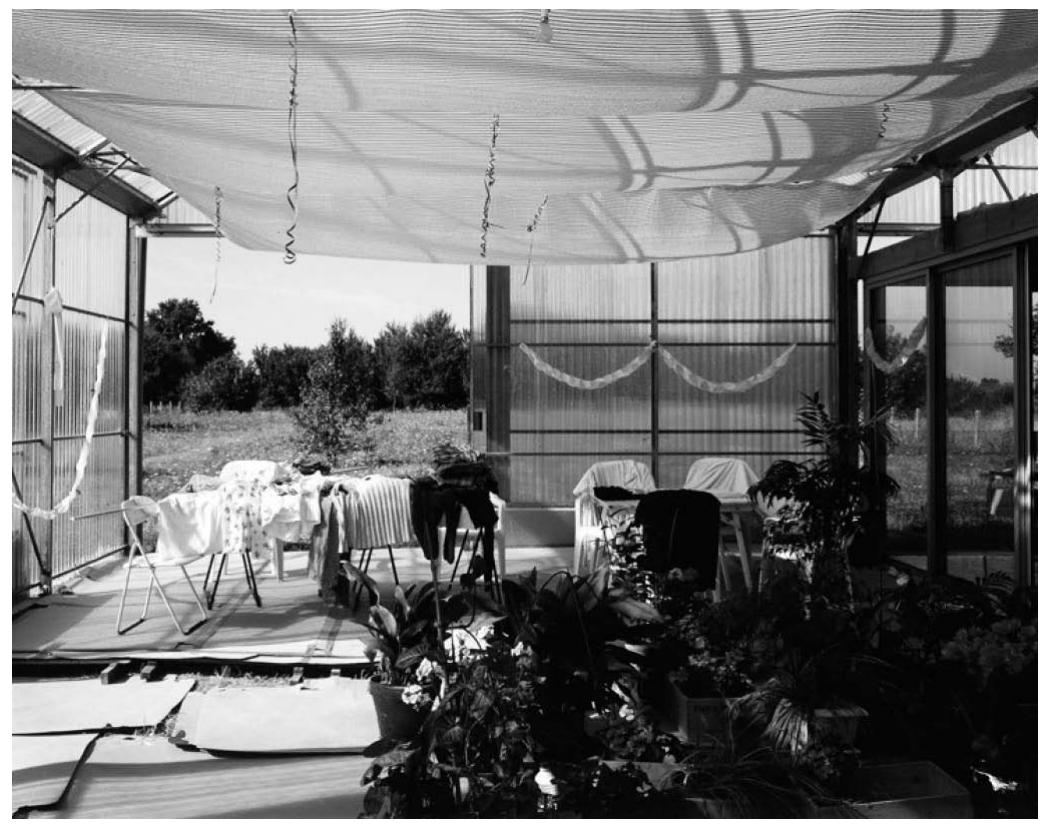

14 leccionados, sino que para ellos lo interesante es la disposición espontánea de los objetos cotidianos "sin retórica" (without rhetoric). Del interior deben encargarse los habitantes y su vida real. El arte de habitar se persigue, incluso en nuestros días, mediante una arquitectura que promueve decididamente la neutralidad del plano, donde ya poco importa qué funciones u objetos deba soportar.

El fenómeno de los objetos ready-made llevó a algunos jóvenes vanguardistas de los años sesenta a radicalizar el enfoque teórico de sus proyectos arquitectónicos, donde la idea de la máquina doméstica empezó a ganar terreno al arte de construir. Banham, por ejemplo, sin experiencia en construcción y libre de toda tradición arquitectónica, propone una visión futurista y prácticamente antiarquitectónica: en su artículo "Un hogar no es una casa" (1965) (Fig. 12), imagina la casa reducida a una bola transparente, la forma más elemental de arquitectura, en cuyo centro se encuentra una máquina que satisface todas las necesidades de la vivienda humana y que no precisa de ninguna contribución del arte de los arquitectos. Esta utopía radical de un desarrollo a ultranza de los objetos funcionales del hábitat confirma, junto con el apogeo del confort del ocupante, la muerte del arte de construir.

\section{UNA NUEVA CONVERGENCIA: EL ARTE DE CONSTRUIR Y EL ARTE DE HABITAR}

Esta visión quizá un poco pesimista se basa en la hipótesis de que se está agrandando la brecha entre los objetos-contenido y la arquitectura-continente y en que la arquitectura mantiene un desfase constante con los objetos, cuya concepción parece siempre más racional, lógica y pertinente. Llegados a este punto, ¿es posible salvar esta distancia entre los objetos y la arquitectura, acentuada tras la industrialización y el impulso de los objetos ready-made?

El arte aplicado al diseño industrial propone respecto a este punto un enfoque artístico de la concepción del objeto de uso cotidiano, si bien existen otras alternativas, como la posibilidad de plantear una generalización absoluta del arte de habitar y aplicarlo directamente a la construcción, es decir: el hágalo-usted-mismo. En ese caso, la principal aportación corresponde a los habitantes, siguiendo el precepto de la exposición de Bernard Rodofsky de 1964, "Architecture Without Architects" ${ }^{43}$, que retoma la idea de la autoconstrucción ilustrada. Según este trabajo, también podemos encontrarnos con otro enfoque que no es nuevo ${ }^{44}$, pero que procura extender el concepto del objeto ready-made a la construcción; es decir: proyectar y ejecutar a partir de elementos preexistentes que pueden encontrarse en catálogos industriales. La aplicación constructiva de los elementos ready-made es muy variada: puede
Figs. 13 y 14. Lacaton y Vassal, vivienda en Coutras (2000), fotografías del exterior y del interior.
42. BANHAM, Reyner, El brutalismo en arquitectura, op. cit., p. 131. Pero Banham opina que esta idea todavía no es lo suficientemente radical: "Con todo, ningún esquema de los Smithson, ni la 'Unité' de Le Corbusier, ni Halen o Park Hill, Sheffield, resulta así adecuado para ofrecer a los que viven en tales construcciones los ambientes domésticos usuales enteramente de nuevo", así que Banham buscará por sí mismo "otra arquitectura" que deje atrás todos los convencionalismos arquitectónicos

43. BANHAM, Reyner, Megastructure, Thames \& Hudson, Londres, 1976, traducido al español por Ramón Font como Megaestructuras, Gustavo Gili, Barcelona, 1978, p. 9: "Ia aportación no profesional a la textura visual urbana" se pone en relieve del mismo modo que en la exposición de Bernard Rodofsky "Architecture without Architects" (1964). De este modo, el arquitecto construye el marco vital y se desentiende de su contenido: "Ios espacios habitables, fuera del control de arquitecto". 
tratarse bien de elementos constitutivos de la arquitectura como ventanas o puertas, que son objetos aislados pero esenciales en la composición, o bien de módulos de grandes superficies que se rigen por la repetición, e incluso de espacios volumétricos completamente prefabricados y listos para instalar como un objeto ready-made.

La vivienda-invernadero concebida a principios del siglo XXI por Lacaton y Vassal puede ser un ejemplo radical pero retroactivo de este último caso: los arquitectos franceses escogen dos invernaderos de catálogo y los transforman en una vivienda con un espacioso jardín de invierno. Si el exterior de la vivienda recuerda a la casa-bola imaginada por Banham, las imágenes publicadas del interior se asemejan más a la de Eames que tanto seducía a los Smithson: el continente y el contenido ponen de manifiesto la idea del arte de habitar en su forma más elemental. Parece que el arte del habitante influye sobre el arte del arquitecto. Al fin y al cabo, la elección y la disposición de estos elementos ready-made continúan siendo "audaces", y a menudo van más allá de los convencionalismos funcionales y estéticos (Figs. 13 y 14).

44. Es cierto que el movimiento moderno ya comenzó a emplear elementos industriales y prefabricados. En "Le Problème de la 'maison minimum'" (Architecture vivante, primavera-verano de 1930, p. 9), Le Corbusier escribe: "La estructura seguirá un estándar: los elementos de la casa [...] La fabricación industrial de los objetos de la vivienda, hasta ahora limitada a los sanitarios, los electrodomésticos o la calefacción, se extenderá infinitamente más allá". En el pabellón de L'Esprit Nouveau, Le Corbusier reproduce la estética de las fábricas con materiales industriales, como ventanas y puertas prefabricadas y transportadas a la obra. Pero la construcción de este pequeño edificio todavía dista mucho de la producción maquinista: la estructura es de hormigón armado, mientras que el muro es de ladrillo, enfoscado y pintado generalmente de blanco. Según Peter Smithson, la producción arquitectónica está sometida a la estética formal: "en el primer periodo de la arquitectura moderna [...] tenían que parecer fabricados por una máquina [...] Las villas de Garches o Savoie [...] como si las hubiera fabricado una máquina, como un objeto unitario, [...]", en "Conversation on Brutalism", Zodiac, n. 4, p. 73. Smithson se muestra convencido de que, por el contrario, la casa Eames es la verdaderamente construida por la máquina, ya que en ella solo se emplean productos prefabricados. La versión ejecutada de la casa Eames es diferente de la propuesta inicial, y es el resultado del ensamblaje de elementos disponibles in situ. Sobre este tema de la "reformulación" de la casa Eames, véase COLOMINA, Beatriz, "Reflexiones acerca de la casa Eames", Injertos 07, Circo: Eames "[...] utiliza el mismo acero de manera diferente [...]". En cuanto a la construcción brutalista con materiales de catálogos industriales, véase SMITHSON, Alison y Peter, "Conversation on Brutalism", op. cit., p. 81 "Que exista esta gran industria de materiales as found no presupone un rechazo del mármol, la escayola y e acero inoxidable. [...] Si el sentido común te dicta que debes hacer algo poético con ladrillo, lo haces con ladrillo".
Sung-Taeg Nam. Assistant professor en la Universidad de Hanyang University, Seúl, Korea. Bachelor of Architecture por la Universidad Nacional de Seúl, Diplome of Maîtrise y Architecte DPLG por la Ecole d'architecture de la ville \& des territoires (EAVT) in Paris Marne-la-Vallée in France, y Ph.D. por la Ecole Polytechnique Fédérale de Lausanne (EPFL) en Suiza, con una tesis titulada The question of Readymade and its architectural appropriation. Ha publicado numerosos artículos en revistas de Arquitectura internacionales como Massilia en Fracia, Matieres en Suiza, Revista de Arquitectura (Ra) en España, etc. Antes de comenzar su labor docente, en 2013 en la Universidad de Hanyang colaboró en cursos de teoría e historia de la arquitectura en la EPFL, como ayudante del profesor Jacques Lucan. Su experiencia profesional ha tenido lugar en Hankil Architect (Seúl), Du Besset et Lyon Architectes (París) y PRS Architectes (Lausanne). 